\title{
MENGENALI FACIAL PALCY PADA TRAUMA WAJAH DAN TATALAKSANA PEMBEDAHAN
}

\author{
Gunawan, Inas Hanan Farihah, Lisa Raihan Lutfia, Muhamad Mahfuzzahroni, \\ Rizka Febriya Moestafa \\ Fakultas Kedokteran, Universitas Mataram, Indonesia \\ Email: Gunawan6720@gmail.com, inashanan2001@gmail.com, \\ lisaraihan51@gmail.com,mmahfuzzhroni@gmail.com,rizkafebriya02@gmail.com
}

\begin{abstract}
Bell's palsy is the most common neurological disorder affecting the cranial nerves with an onset that is rapid and unilateral, and it is common cause of facial paralysis worldwide. Bell's palsy occurs due to compression or enlargement of the stylomastoid foramen and causes nerve obstruction or damage caused by trauma, infection, inflammation, autoimmune, ischemic. This article aims to review bell's palsy, specifically motor nerve alignment, surgical disorders and management of bell's palsy. Source searches were carried out on online portals for journal publications such as Google Scholar (scholar.google.com) and the National Centre for Biotechnology Information/NCBI (ncbi.nlm.nih.gov), with the keyword "Facial palcy, dan Bell's palcy". In the United States, the annual incidence of Bell's palsy is approximately 23 cases per 100,000 people. Permanent facial paralysis and non-transient functional deficits are the main indications for surgical reconstruction of facial nerve function. The indications for surgery depend on the severity of the nerve lesion, blunt trauma that causes nondegenerative neuropraxia does not require surgical reconstruction, whereas disorders leading to degenerative neurotmesis require surgery.
\end{abstract}

Keyword: Facial palcy; Facial Nerve Trauma; Bell's palcy; surgical management

\section{Abstrak}

Bell's palsy adalah gangguan neurologis paling umum yang mempengaruhi saraf kranial dengan onset yang cepat dan unilateral, dan merupakan penyebab umum kelumpuhan wajah di seluruh dunia. Bell's palsy terjadi karena kompresi atau pembesaran foramen stylomastoid dan menyebabkan obstruksi atau kerusakan saraf yang disebabkan oleh trauma, infeksi, peradangan, autoimun, iskemia. Artikel ini bertujuan untuk meninjau bell's palsy, khususnya keselarasan saraf motorik, gangguan bedah dan manajemen bell's palsy. Pencarian sumber dilakukan di portal online publikasi jurnal seperti Google Scholar, dan Nation Center for Biotechnology Information/ NCBI dengan kata kunci "Facial palcy, dan Bell's palcy". Di Amerika Serikat, insiden tahunan Bell's palsy adalah sekitar 23 kasus per 100.000 orang. Kelumpuhan wajah permanen dan defisit fungsional non-sementara merupakan indikasi utama untuk rekonstruksi bedah fungsi saraf

\footnotetext{
Copyright holder: Gunawan, Inas Hanan Farihah, Lisa Raihan Lutfia, Muhamad Mahfuzzahroni, Rizka Febriya Moestafa (2021)

DOI : https://doi.org/10.54543/fusion.v1i11.100

Published by : Rifa Institute
} 
wajah. Indikasi pembedahan tergantung pada beratnya lesi saraf, trauma tumpul yang menyebabkan neuropraxia non degeneratif tidak memerlukan rekonstruksi bedah, sedangkan kelainan yang mengarah pada neurotmesis degeneratif memerlukan pembedahan.

Kata kunci: Facial palcy; Facial Nerve Trauma; Bell's palcy; surgical management.

Diterima: 17-10-2021

Direvisi: 12-11-2021

Diterbitkan: 20-11-2021

\section{Pendahuluan}

Bell's palsy merupakan penyebab paling umum dari kelumpuhan wajah unilateral. Bell's palsy adalah kelumpuhan saraf wajah yang bersifat akut, unilateral, perifer, dan neuron motorik bawah yang dapat sembuh secara bertahap (Holland \& Bernstein, 2014). Etiologi dari Bell's palsy masih belum diketahui pasti, meskipun kelainan tersebut tampaknya terjadi akibat peradangan pada saraf - saraf akibat infeksi virus, inflamasi, autoimun, iskemik, dan trauma (Warner, Hutchison, Varacallo, 2020).

Bell's palsy adalah salah satu gangguan neurologis paling umum yang mempengaruhi saraf kranial, dan merupakan penyebab paling umum dari kelumpuhan wajah di seluruh dunia. Diperkirakan sekitar 60-75\% kasus paralisis wajah unilateral akut. Bell's palsy lebih sering terjadi pada orang dewasa, penderita diabetes, dan wanita hamil. Di Amerika Serikat, kejadian tahunan Bell's palsy kira-kira 23 kasus per 100.000 orang. Secara internasional, insiden tertinggi ditemukan dalam sebuah penelitian di Seckori, Jepang, pada tahun 1986, dan insiden terendah ditemukan di Swedia pada tahun 1971. Sebagian besar studi populasi umumnya menunjukkan insiden tahunan 15-30 kasus per 100.000 populasi (Heckmann et al., 2008).

Pembedahan dapat dipertimbangkan pada pasien dengan Bell's palsy yang mengalami perbaikan dengan terapi medis dan dengan degenerasi aksonal lebih dari $90 \%$. Beberapa penelitian menunjukkan bahwa $51 \%$ penderita mengalami pemulihan saraf wajah dengan menjalani terapi pembedahan dengan masa pemulihan memakan waktu hingga 1 tahun. Keputusan untuk intervensi bedah kemungkinan besar akan didasarkan pada apakah cedera saraf kemungkinan neuropraksia (yaitu, dapat dipulihkan) atau terputus. (Mistry \& Al-Sayed, 2020).

\section{Metode Penelitian}

Penulisan artikel ini menggunakan berbagai jenis sumber yang berasal dari jurnal ilmiah. Pencarian sumber dilakukan di portal online publikasi jurnal seperti National Center for Biotechnology Information / NCBI (ncbi.nlm.nih.gov) dan Google Scholar (scholar.google.com). Kata kunci yang digunakan "Facial palcy", "Bell's palcy". "Facial Nerve Trauma", "Motoric Nerve Trauma", "Sensoric Nerve Trauma", "Plastic surgery”. 
Gunawan, Inas Hanan Farihah, Lisa Raihan Lutfia, Muhamad Mahfuzzahroni, Rizka Febriya Moestafa

\section{Hasil dan Pembahasan \\ Definisi}

Istilah facial palsy merangkum kehilangan seluruh (paresis) serta kehilangan total (kelumpuhan) fungsi saraf wajah. Kelumpuhan wajah permanen dan defisit fungsional non- transien merupakan indikasi utama untuk rekonstruksi bedah fungsi saraf wajah (Volk, Pantel, \& Guntinas-Lichius, 2010). Salah satu penyebab tersering facial paslcy adalah bell's palcy. Bell palsy adalah kelumpuhan perifer yang paling umum dari saraf kranial ketujuh dengan onset yang cepat dan unilateral (Warner, Hutchison, \& Varacallo, 2020).

\section{Epidemiologi}

Facial palcy adalah penyakit umum dengan insiden tahunan 15-30 per 100.000 penduduk. Insiden meningkat seiring bertambahnya usia. Genetik keluarga telah ditemukan pada 4-14\% kasus. Insiden Bell's palsy mencapai maksimum antara usia 1545 tahun, penyakit ini secara signifikan kurang umum di bawah usia 15 tahun dan di atas usia 60. Kedua jenis kelamin sama-sama terpengaruh (Mustafa \& Sulaiman, 2018).

Trauma sendiri menyumbang $10 \%$ sampai $23 \%$ dari semua kelumpuhan saraf wajah. Ini memiliki implikasi pada kualitas hidup pasien karena peran saraf wajah dalam beberapa proses penting. Saraf wajah mengalami cedera pada $7 \%$ hingga $10 \%$ dari semua fraktur tulang temporal. Kejadian yang paling umum diakibatkan oleh tabrakan kendaraan, perkelahian, dan jatuh. Akibatnya, sekitar 90\% dari patah tulang temporal dikaitkan dengan cedera intrakranial, dan 10\% terkait dengan cedera tulang belakang leher (Mistry \& Al-Sayed, 2020).

Kelumpuhan saraf facial adalah penyakit saraf kranial yang paling umum. Bentuk idiopatiknya (Bell's palsy) terdapat 60-75\% kasus. 7-40 kasus muncul per 100.000 orang per tahun, insidensinya serupa pada pria dan wanita. Insidensinya mungkin lebih tinggi pada wanita hamil dan lebih rendah pada anak-anak (Heckmann et al., 2008).

Insiden tahunan berkisar 15 sampai 20 per 100.000 dengan 40.000 kasus baru setiap tahun dan risiko seumur hidup mencapai 1 dari 60. Penderita dengan tingkat kekambuhan $8 \%$ sampai $12 \%$. Bahkan tanpa pengobatan, $70 \%$ pasien akan sembuh total. Tidak ada preferensi jenis kelamin atau ras, dan kelumpuhan dapat terjadi pada usia berapa pun, tetapi lebih banyak kasus terlihat pada 40 tahun (Warner et al., 2020).

\section{Etiologi}

Facial palsy atau kelumpuhan wajah dapat disebabkan oleh berbagai macam penyebab. Daftar penyebab atau etiologi facial palcy dapat dilihat pada tabel berikut 


\begin{tabular}{ll} 
Table 1. Classification of Facial Nerve Palsy by \\
Etiology with Examples in Each Category \\
\hline Cause of Facial Palsy & Condition/Characteristics \\
\hline Congenital & \\
Idiopathic & Mandibular division palsy \\
Syndromic & Möbius syndrome \\
Nonsyndromic & Birth trauma \\
Acquired & \\
Idiopathic & \\
Traumatic & \\
Central & Cerebral event \\
Intratemporal & Temporal bone fracture \\
Facial & Facial laceration \\
Tumor & Acoustic neuroma \\
Central & Cholesteatoma \\
Intratemporal & Parotid tumor \\
Facial & \\
Inflammatory & Bell's palsy \\
Viral & Middle ear infection \\
Bacterial & Myaesthenia gravis \\
Neuromuscular &
\end{tabular}

Tabel 1. Cause of Facial Palsy Condition/Characteristics (Fattah, Borschel, Manktelow, Bezuhly, \& Zuker, 2012).

Etiologi dari Bell's palsy masih belum diketahui pasti, meskipun kelainan tersebut tampaknya terjadi akibat peradangan pada saraf - saraf akibat infeksi virus, inflamasi, autoimun, iskemik, dan trauma (Newadkar, Chaudhari, \& Khalekar, 2016).

Etiologi facial palsy akibat fraktur yang melibatkan bagian petrosa tulang temporal dan luka wajah yang memotong cabang saraf wajah dapat menyebabkan kelumpuhan saraf wajah. Fraktur tulang temporal biasanya terjadi secara unilateral dan diklasifikasikan menurut bidang fraktur sepanjang petrosus ridge (yaitu, longitudinal vs transversal. Selain itu, cedera iatrogenik selama operasi otological, parotis, dan neuroma akustik dapat mengakibatkan kerusakan traumatis pada tulang belakang. saraf wajah dan cedera regangan (Walker, Mistry, Mazzoni, 2021).

Pada kasus trauma, terutama disebabkan oleh patah tulang temporal atau cedera wajah akibat kecelakaan lalu lintas atau korban kejahatan, diindikasikan untuk rekonstruksi bedah yang lebih awal dan segera. Indikasi pembedahan tergantung pada beratnya lesi saraf, trauma tumpul yang menyebabkan neuropraksia non degeneratif tidak memerlukan rekonstruksi bedah, sedangkan gangguan yang mengarah ke neurotmesis degeneratif memerlukan pembedahan. Tumor apa pun dalam perjalanan saraf wajah dari batang otak ke pinggiran dapat menyebabkan kelumpuhan wajah atau perawatan bedah tumor mungkin menjadi penyebab kelumpuhan wajah (Volk et al., 2010). 
Gunawan, Inas Hanan Farihah, Lisa Raihan Lutfia, Muhamad Mahfuzzahroni, Rizka Febriya Moestafa

\section{Faktor Resiko}

Faktor risiko yang terkait dengan hasil yang buruk termasuk kelumpuhan total, usia lebih dari 60, dan penurunan air liur atau rasa di sisi ipsilateral (Warner, Hutchison, Varacallo, 2020).

\section{Gejala klinis}

- Tipe Flaccid

Manifestasi klinis tipe flaccid umumnya ditemukan pada facial paralysis tahap akut. Ada penurunan umum pada daerah yang lumpuh dan deformasi otot wajah, menyebabkan asimetrisitas yang statis dan dinamis. Saat paruh atas wajah istirahat, terjadi ptosis pada alis yang memperburuk dermatokalasis yang membebani kelopak mata atas. Otot orbicularis oculi melemah. Kelopak mata bawah tidak mempunyai penyangga, menyebabkan mata bulat atau bahkan entropion akibat hilangnya tonus orbicularis (Guerreschi \& Labbé, 2019). Di bagian bawah wajah, garis median bergeser ke sisi yang berlawanan dari wajah yang lumpuh, dan pipi menjadi lembek dan gemuk. Bagian tengah mulut terkulai. Ekspresi yang spontan meningkatkan torsi wajah. Hemilip atas dan bawah meregang dan memanjang.

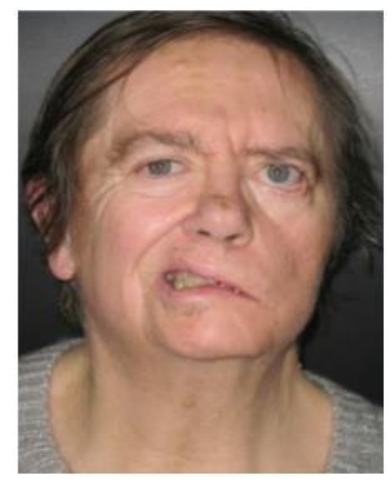

Gambar 1. Tipe Flaccid (Guerreschi, Labbé, 2019).

- $\quad$ Tipe Paretic

Tipe paretic mirip dengan tipe flaccid, tetapi tidak parah. Simetris statis dapat dianggap normal. Hanya ekspresi yang menunjukkan asimetrisitas wajah. Alis asimetris terlihat di bagian atas wajah. Kita bisa melihat gerakan bibir yang ke atas kurang saat tersenyum. Bibir bawah menyimpang ke arah kontralateral. Gigi bawah lebih terlihat di sisi berlawanan dari sisi yang mengalami kelumpuhan ketika pasien berbicara atau tersenyum (Guerreschi, Labbé, 2019). 


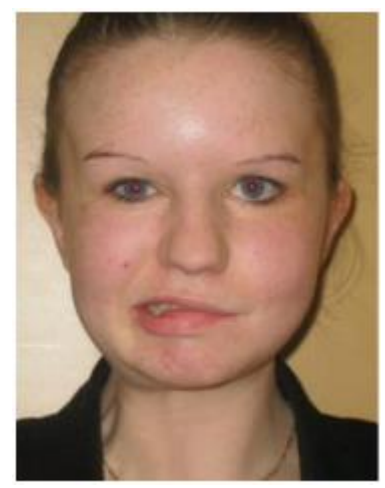

Gambar 2. Tipe Paretic (Guerreschi \& Labbé, 2019).

- Tipe Spastic

Beberapa pasien akan mengalami gangguan motorik, termasuk kejang, kokontraktur yang berlebihan, atau sinkinesis, yang menyebabkan kejang hemifasial pasca-paralisis. Kejangnya bisa tetap klonik dan terpisah atau menjadi lebih parah, muncul sebagai kontraktur tonik, yang bisa saja lebih menyakitkan atau kurang menyakitkan. Ini terkait dengan gangguan motorik progresif. Situasi klinis ini meningkat karena stres, kelelahan, atau emosi. Beberapa kelompok otot dapat terpengaruh oleh kejang ini. Untuk kelopak mata bagian bawah otot, kita berbicara tentang blepharospasm. Ada beberapa kontraktur yang juga disebut sinkinesis. Hal ini harus diskrining dengan hati-hati selama pemeriksaan klinis lengkap, bisa diperhatikan saat pasien berbicara. Kita juga bisa melihatnya pada ekspresi wajah tertentu. Untuk membuatnya jelas, pasien harus melakukan ekspresi wajah tertentu untuk memungkinkan kontraksi kelompok otot tertentu. Respon kontras abnormal dari kelompok otot lain yang seharusnya beristirahat disebut co-contracture atau synkinesis. Yang paling sering termasuk adalah frontalis / mentalis, orbicularis oculi / platysma, orbicularis oris / orbicularis oculi, dan zygomati- cus mayor / depressor anguli oris. Kontraktur dari depressor anguli oris dan platysma yang dipicu oleh gerakan otot elevator bibir atas dan komisura labial sendiri dapat menghambat senyuman (Guerreschi \& Labbé, 2019).

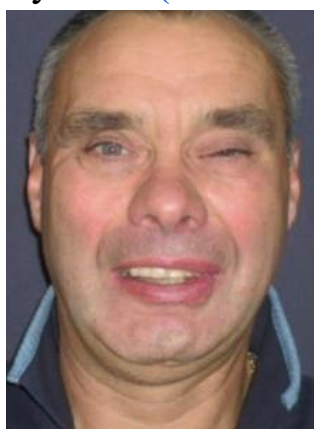

Gambar 3. Tipe Spastic (Guerreschi, Labbé, 2019).

- $\quad$ Tipe Hyperactivity

Di sisi kontralateral, ada kemungkinan hiperaktivitas reaksional dari otot. Otot frontalis menonjolkan kerutan dahi dan mengangkat alis bahkan saat istirahat. Sering terjadi hiperaktif pada otot elevator bibir, ketika tersenyum, mulut 
ditarik secara berlebihan ke sisi kontralateral, sehingga sebagian besar gigi terbuka. Depresor hiperaktif labii inferioris merusak elokusi dengan mengarahkan bibir bawah ke arah luar dan dengan menggeser garis median dari bibir inferior ke arah sisi yang tidak terpengaruh. Terakhir, pita platysma leher di sisi yang sehat merupakan tanda hiperaktivitas otot platysma (Guerreschi, Labbé, 2019).

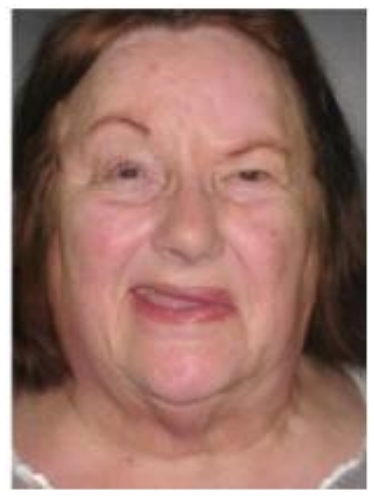

Gambar 4. Tipe Hyperactivity (Guerreschi, Labbé, 2019).

\section{Patofisiologi}

Bell's palsy diperkirakan terjadi akibat kompresi saraf kranial ketujuh di ganglion genikulata. Bagian pertama dari kanal wajah, segmen labirin, adalah yang tersempit dan disinilah sebagian besar kasus kompresi terjadi. Karena saluran wajah yang sempit, peradangan menyebabkan kompresi dan iskemia saraf. Temuan paling umum adalah kelemahan wajah sepihak yang meliputi otot-otot dahi (Warner, Hutchison, Varacallo, 2020).

Hipotesis utama saat ini tentang patofisiologi kelumpuhan saraf wajah melibatkan pengaktifan kembali infeksi virus herpes simpleks (HSV tipe 1) atau respons inflamasi autoimun yang dimediasi sel. Hipotesis virus didukung oleh demonstrasi DNA virus herpes simpleks di ganglion genikulata dan cairan endoneural yang diperoleh saat pembedahan dekompresi dan dalam air liur pasien yang terkena. Diasumsikan bahwa episode dapat dipicu oleh stres atau oleh infeksi jenis lain, dalam analogi dengan herpes labialis (Heckmann, et al., 2019).

Dalam hipotesis autoimun, kelumpuhan saraf wajah idiopatik dianggap sebagai varian mononeuritik dari sindrom Guillain-Barré (GBS). Temuan pendukung termasuk penurunan sel penekan $\mathrm{T}$ dan peningkatan limfosit $\mathrm{B}$ pada pasien yang terkena, bersama dengan peningkatan konsentrasi serum interleukin-1, interleukin-6, dan tumor necrosis factor alpha. Ada juga pengamatan epidemiologi yang menarik dari peningkatan yang signifikan dalam kejadian kelumpuhan saraf wajah perifer di Swiss setelah pengenalan vaksinasi influenza intranasal. Diasumsikan bahwa infeksi (atau vaksinasi, seperti di Swiss) dapat memicu respons imun mononeuritik yang diarahkan ke antigen mielin di saraf tepi, dalam hal ini saraf wajah (Murthy \& Saxena, 2011).

Bell's Palsy dapat berkembang dalam proses beberapa langkah yang dimulai dengan peradangan yang menyebabkan edema dan pembengkakan. Hal ini dapat menyebabkan kompresi saraf di kanal falopi, di mana saraf normal melewati selubung 
tulang tersempitnya, hipoperfusi (pencekikan) saraf terjadi, menyebabkan kerusakan akson dan selubung mielin dan disfungsi saraf. Peran yang mungkin dari faktor-faktor selanjutnya (cuaca, paparan dingin atau udara dingin) belum ditentukan secara meyakinkan, ada bukti yang lemah untuk hubungan dengan perubahan cepat suhu dan tekanan atmosfer (Heckmann et al., 2008).

\section{Prognosis}

Kelumpuhan wajah menyebabkan morbiditas yang signifikan, dan pengobatannya bertujuan untuk mengatasi fungsi, estetika, dan aspek psikologis. Yang terpenting adalah pentingnya untuk mencocokkan keinginan pasien dengan teknik rekonstruksi untuk mencapai kepuasan pasien (Fattah et al., 2012). Salah satu penelitian menunjukkan bahwa manajemen non operatif dikaitkan dengan pemulihan saraf wajah di $63 \%$ dari kelumpuhan saraf wajah onset langsung dibandingkan dengan 51\% yang menjalani dekompresi saraf wajah. Pemulihan ini bisa memakan waktu hingga 1 tahun bahkan setelah operasi, dengan beberapa derajat sisa synkinesis dan kelemahan otot dalam beberapa kasus (Mistry dan Al-Sayed, 2020).

Untuk prognosis bell's palsy sendiri, pada 71\% kasus yang tidak diobati, dapat sembuh total tanpa pengobatan. Pengobatan dengan kortikosteroid terbukti meningkatkan kemungkinan pemulihan saraf yang lebih baik. Kekambuhan memang terjadi, dan satu penelitian menemukan tingkat kekambuhan sebesar 12\%. Studi lain melaporkan hingga $10 \%$ pasien yang menderita BP akan mengalami kekambuhan gejala setelah latensi ratarata 10 tahun. 5-15\% tingkat kekambuhan telah dilaporkan. Semakin lama pemulihan, semakin besar kemungkinan sisa gejala sisa dapat berkembang (Warner, Hutchison, Varacallo, 2020).

\section{Komplikasi}

Komplikasi dari fraktur tulang temporal termasuk kebocoran CSF, meningitis, fistula CSF, pembentukan kolesteatoma, stenosis kanal pendengaran eksternal, dan cedera karotis intratemporal. Komplikasi dari kelumpuhan wajah bell's palsy antara lain kekeringan kornea yang menyebabkan hilangnya penglihatan, kerusakan permanen pada saraf wajah, dan pertumbuhan serabut saraf yang tidak normal (Warner et al., 2020).

Komplikasi kelumpuhan saraf wajah juga termasuk kerusakan emosional dan psikologis bersama dengan oftalmologis, otologis, rinologis, dan dampak pada rasa. Konsekuensi oftalmologis akibat gangguan lakrimasi, ektropion, dan epifora dapat menyebabkan paparan keratopati, yang dapat menyebabkan kebutaan. Konsekuensi otologis termasuk penurunan pendengaran. Dukungan otot yang terganggu ke katup hidung dapat menyebabkan penyumbatan hidung. Dampak pada otot perioral dapat mengakibatkan aktivitas menelan yang buruk dan kompetensi oral yang tidak memadai, sedangkan kerusakan cabang chorda tympani pada saraf wajah dapat menyebabkan gangguan atau perubahan rasa (Mistry \& Al-Sayed, 2020).

\section{Tatalaksana}


Gunawan, Inas Hanan Farihah, Lisa Raihan Lutfia, Muhamad Mahfuzzahroni, Rizka Febriya Moestafa

\section{- Terapi Pharmacologi}

Perawatan yang dipertimbangkan untuk Bell's palsy termasuk kortikosteroid oral (prednisolon) dan obat antivirus. Meskipun etiologi Bell's palsy tidak pasti, diketahui bahwa peradangan dan edema saraf wajah bertanggung jawab atas gejalanya. Kortikosteroid karena itu telah digunakan untuk efek anti-inflamasi (Somasundara \& Sullivan, 2017).

Pada penggunaan kortikosteroid, efek maksimal terlihat ketika steroid dimulai dalam waktu 72 jam dari timbulnya gejala. Tidak ada rejimen optimal, tetapi pada orang dewasa 50-60 mg prednisolon setiap hari selama 10 hari telah umum digunakan.6,7 Prednisolon telah digunakan dengan dosis $1 \mathrm{mg} / \mathrm{kg} / \mathrm{hari}$ hingga maksimum $80 \mathrm{mg}$ dalam beberapa penelitian. Dosis lebih dari $120 \mathrm{mg} / \mathrm{hari}$ telah digunakan dengan aman pada pasien diabetes (Zhao, Feng, \& Gao, 2015).

Obat antivirus yang digunakan dalam beberapa uji coba adalah asiklovir (400 mg lima kali sehari selama lima hari) atau valasiklovir (1000 mg/hari selama lima hari). Saat ini tidak ada bukti yang mendukung penggunaan obat antivirus itu sendiri, dan ada ketidakpastian mengenai manfaat menambahkannya ke kortikosteroid (Somasundara \& Sullivan, 2017).

\section{- Terapi Pembedahan}

Ada beberapa perdebatan mengenai kriteria pasien untuk dilakukan operasi pada trauma saraf wajah. Beberapa penelitian menunjukkan bahwa 51\% penderita mengalami pemulihan saraf wajah dengan menjalani terapi pembedahan dengan masa pemulihan memakan waktu hingga 1 tahun. Keputusan untuk intervensi bedah kemungkinan besar akan didasarkan pada apakah cedera saraf kemungkinan neuropraksia (yaitu, dapat dipulihkan) atau terputus / hancur (yaitu, tidak dapat dipulihkan). Kunci penatalaksanaannya adalah mengidentifikasi onset akut, onset tertunda, dan mereka yang memiliki keterlambatan diagnosis. Terdapat kesulitan dalam mengkategorikan pasien untuk dilakukan pembedahan. Misalnya, pasien yang mengikuti tabrakan lalu lintas jalan dapat diintubasi dan dibius karena cedera lainnya. Pasien-pasien ini harus diperlakukan sebagai kelumpuhan wajah yang onset segera untuk menghindari manajemen konservatif yang tidak tepat (Mistry \& Al-Sayed, 2020).

Jika segera terjadi kelumpuhan total, maka eksplorasi bedah untuk dekompresi saraf wajah diperlukan segera setelah kondisi pasien memungkinkan, hal ini biasanya terjadi dalam kurun waktu 2 sampai 3 minggu. Jika ada diagnosis kelumpuhan yang tertunda dengan degenerasi saraf $90 \%$ atau lebih pada Electroneuronography (ENoG), maka dekompresi bedah juga diindikasikan. Beberapa literatur menyarankan penggunaan kombinasi elektrodiagnostik dan CT, terutama jika waktu kelumpuhan tidak diketahui (Mistry \& Al-Sayed, 2020). Beberapa pilihan untuk menangani cedera saraf bergantung pada temuan operasi. Kerusakan saraf sekunder akibat benturan (saraf masih utuh), dapat dilakukan dengan Teknik dekompresi selubung epineural secara proksimal ke distal. Prosedur ini lebih umum dan sering disebabkan oleh hal-hal seperti trauma 
regangan, benturan oleh spikula tulang, atau hematoma intraneural. Operasi ini sering tertunda karena pengobatan cedera yang mengancam jiwa yang diderita akibat trauma asli, penundaan rujukan, atau status neurologis yang buruk. Penundaan ini tidak memperburuk prognosis, dengan dilakukan pembedahan terbukti dapat dilakukan tiga bulan setelah cedera (Mistry \& Al-Sayed, 2020).

\section{Manajemen Bedah Kelumpuhan Wajah}

- Pemanjangan Myoplasty Temporalis

Otot temporalis adalah otot datar dan lebar yang berasal dari sisi tengkorak dan tendonnya melewati ke rahang bawah (mandibula), sehingga memungkinkannya untuk menutup dengan kuat. Otot temporalis adalah salah satu otot yang digunakan dalam menggigit dan mengunyah. Dipersarafi oleh saraf kranial kelima (saraf trigeminal), sehingga tidak terpengaruh pada kelumpuhan saraf wajah (saraf facialis). Terdapat empat otot yang bertanggung jawab dalam proses menggigit sehingga dapat digunakan untuk memperbaiki kelumpuhan wajah. Sehingga salah satu otot dapat digunakan sebagai donor untuk fungsi lain tanpa mempengaruhi kemampuan menggigit secara normal. Proses menggigit adalah fungsi analogi untuk tersenyum. Dengan kata lain, sampai taraf tertentu, ketika seseorang ingin tersenyum, ada elemen menggigit atau menutup rahang yang terjadi. Ini sangat penting dalam merencanakan menciptakan kembali senyum yang dinamis pada penderita facial falcy (Gordin, Lee, Ducic, \& Arnaoutakis, 2015).

Pemanjangan Myoplasty Temporalis (transfer otot temporalis) merupakan suatu hal yang penting dalam standar perawatan saat ini untuk mengembalikan senyuman yang dinamis karena memungkinkan tindakan tanpa revaskularisasi atau reinnervasi (Guerreschi P, 2019).Prosedur ini berbeda dengan "transfer tendon temporalis", yang merupakan versi yang lebih singkat dari mioplasti temporalis atau transfer otot. Perbaikan pada transfer otot temporalis awalnya dikembangkan oleh McLaughlin dan dikembangkan lebih lanjut oleh Labbe dan Huault. Teknik ini melibatkan pengangkatan tendon temporalis dari penyisipannya pada proses koronoid mandibula dan menempelkannya kembali ke komisura oral melalui insisi transbuccal atau lipatan nasolabial. Modifikasi prosedur melibatkan pengangkatan proses koronoid, di mana fascia lata dapat dilewatkan dan kemudian ditambatkan ke otot-otot wajah (Gordin et al., 2015).
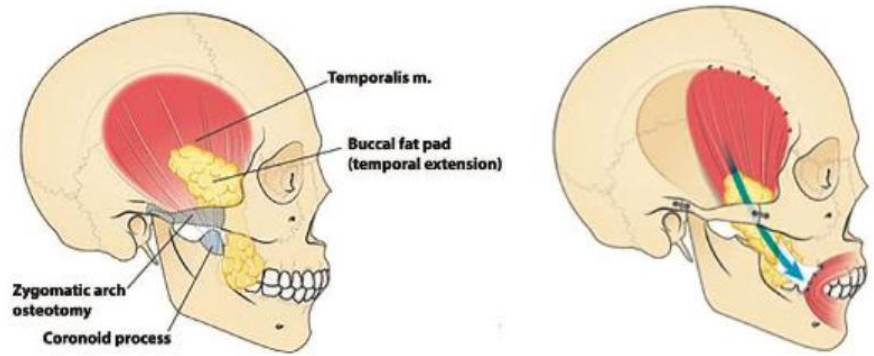

Gambar 5. Pemanjangan Myoplasty Temporalis(Gordin, Eli., et al, 2014).

- Penyisipan Distal dari Transfer Otot ke Bibir Atas dan Komisura 
Setiap transfer otot dinamis harus dilakukan dengan hati-hati ke daerah peribuccal baik dengan pendekatan langsung melalui lipatan nasolabial atau dengan pendekatan bedah, seperti pendekatan preaurikuler. Dalam prosedur pemanjangan myoplasty temporalis, pendekatan lipatan nasolabial lebih disukai karena memungkinkan akses yang lebih mudah ke bantalan lemak bukal sehingga transfer tendon yang baik dapat dilakukan (Zhang et al., 2020).

Sayatan dilakukan di sepanjang garis rambut dari tengah dahi melengkung di sepanjang jalur pengencangan wajah dan berakhir di daun telinga. Sayatan kedua ditempatkan di persimpangan bibir-pipi (lipatan nasolabial). Setelah anestesi dan obat lokal tambahan disuntikkan, dahi dan sayatan wajah dibuat. Otot temporalis awalnya dimobilisasi. Otot dilepaskan seluruhnya ke dalam pada posisi aslinya (di dalam fossa temporalis) sehingga otot itu hanya bergantung pada saraf dan suplai darahnya. Tulang zygomatik akan terputus sementara untuk memberikan akses dalam proses penyisipan. Bagian tulang mandibula (prosesus koronoid) tempat tendon menempel kemudian akan diputus dengan tendon utuh yang melekat. Selanjutnya, melalui sayatan nasolabial, sebuah terowongan dibuat untuk merekatkan tendon dan prosesus koronoid. Tulang kemudian dipisahkan dari tendon, dan tendon dimasukkan tepat di sepanjang sudut mulut dan bibir atas (Gordin et al., 2015).

Otot diputar pada posisi biasanya sebanyak 90 derajat untuk memberikan tambahan panjang pada tendon, oleh karena itu, proses ini disebut mioplasti "memanjang". Manuver ini memungkinkan otot untuk melakukan konfigurasi ulang di sepanjang posisi barunya dan memberikan ekskursi maksimal tanpa memerlukan cangkok tendon atau fasia lata. Setelah mengamankan otot dan tendon pada posisi barunya, otot tersebut kemudian distimulasi untuk menentukan kecukupan dan derajat gerakannya. Hal ini juga memungkinkan penyesuaian dilakukan sebelum penutupan operasi untuk mendapatkan senyuman terbaik (Gordin et al., 2015). 

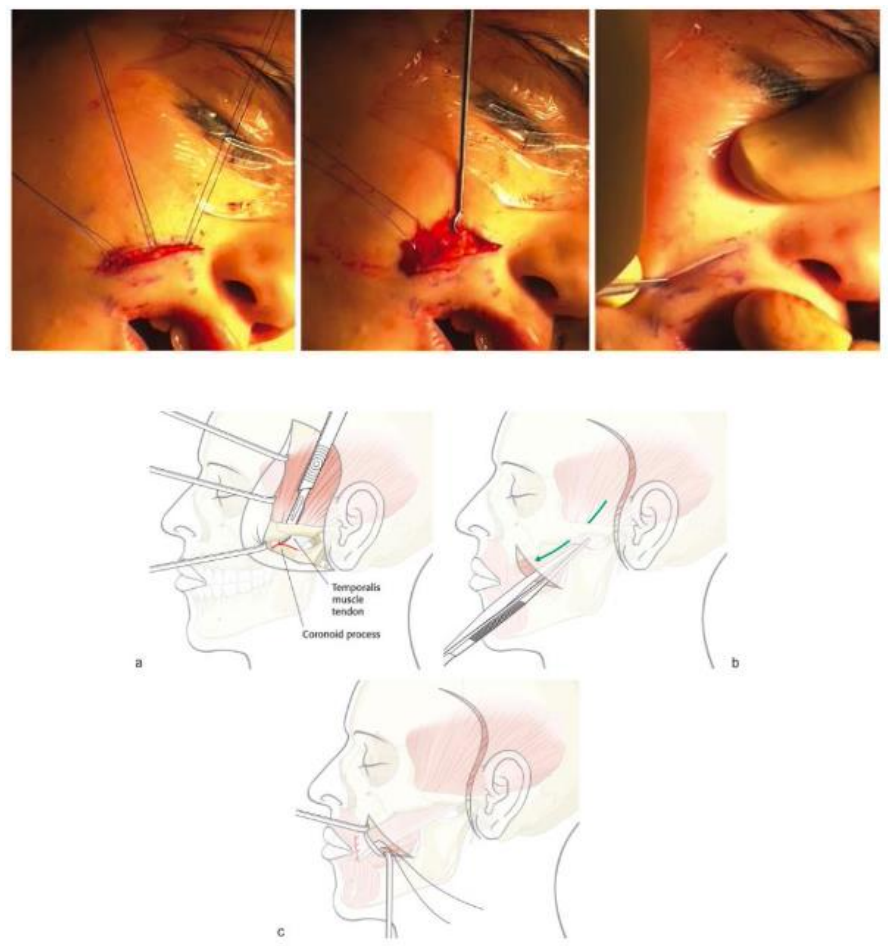

Gambar 6. Penyisipan Distal dari Transfer (Gordin et al., 2015)

\section{- Rehabilitasi Pasca Transfer Dinamis}

Rehabilitasi dengan ahli terapi wicara atau fisioterapis sangat penting dalam memastikan kualitas hasil. Hal ini harus dilaksanakan sejak dini dan durasinya harus cukup konsekuen. Kontrol otot dapat dimulai bahkan sebelum prosedur pembedahan, terutama untuk pemanjangan mioplasti temporalis. Pasca operasi, diperlukan istirahat otot selama 3 minggu untuk memungkinkan penyembuhan insersi tendon. Dalam kasus transfer otot yang dipersarafi oleh saraf kranial kelima, kerja bibir dan senyuman dengan elevasi komisura dilakukan dengan meminta gerakan mandibula: menggigit, retropulsi, dan gerakan lateral. Kontraksi yang tidak tergantung dari gerakan mandibula dengan cepat diperoleh (Guerreschi P,2019). 
Gunawan, Inas Hanan Farihah, Lisa Raihan Lutfia, Muhamad Mahfuzzahroni, Rizka Febriya Moestafa
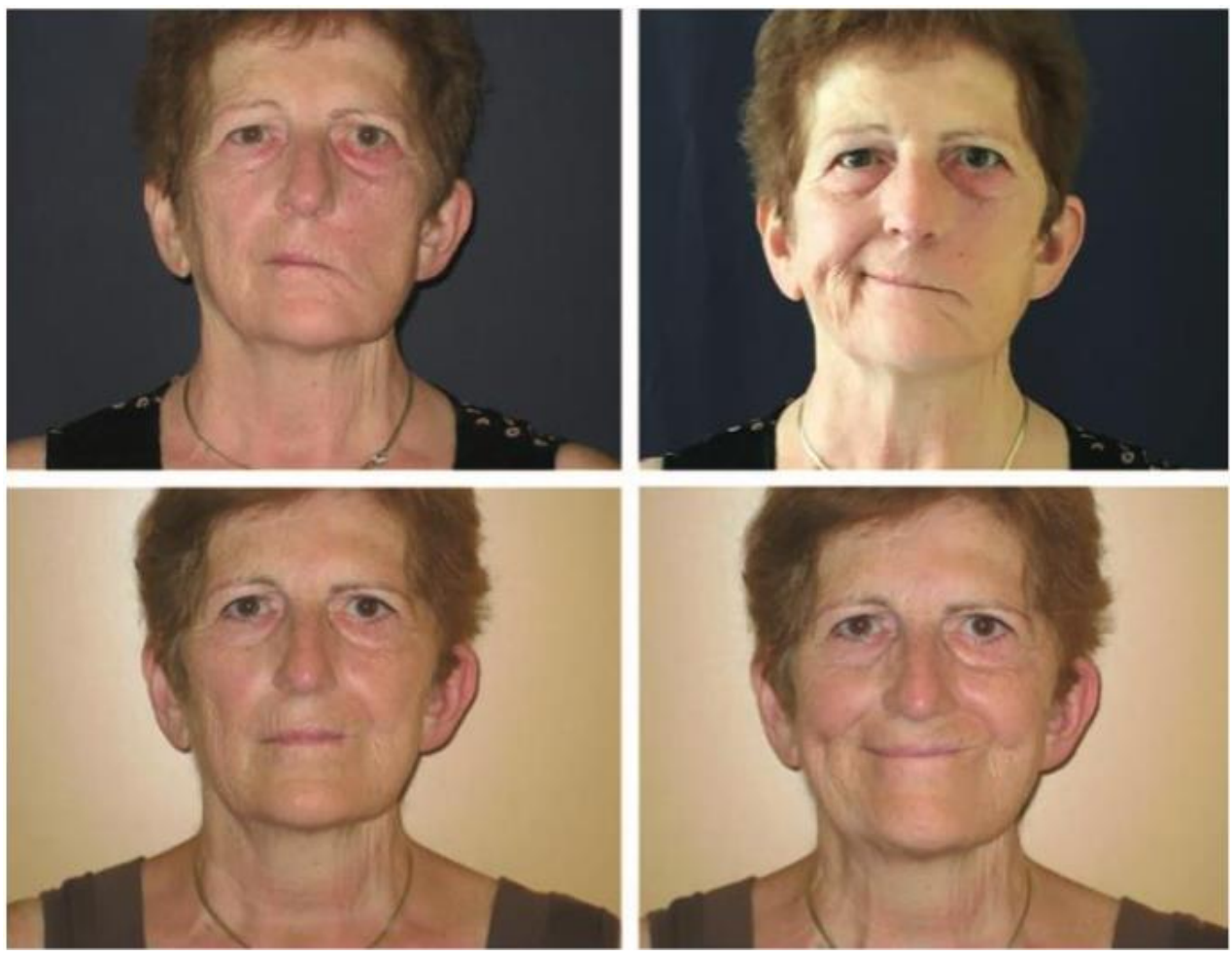

Gambar 7. Rehabilitasi Pasca Transfer Dinamis (Guerreschi P,2019).

\section{Kesimpulan}

Kelumpuhan wajah permanen dan defisit fungsional non-sementara merupakan indikasi utama untuk rekonstruksi bedah fungsi saraf wajah. Indikasi pembedahan tergantung pada beratnya lesi saraf, trauma tumpul yang menyebabkan neuropraxia non degeneratif tidak memerlukan rekonstruksi bedah, sedangkan kelainan yang mengarah pada neurotmesis degeneratif memerlukan pembedahan. 


\section{BIBLIOGRAFI}

Fattah, Adel, Borschel, Gregory H., Manktelow, Ralph T., Bezuhly, Michael, \& Zuker, Ron M. (2012). Facial palsy and reconstruction. Plastic and Reconstructive Surgery, 129(2), 340e-352e. Google Scholar

Gordin, Eli, Lee, Thomas S., Ducic, Yadranko, \& Arnaoutakis, Demetri. (2015). Facial nerve trauma: evaluation and considerations in management. Craniomaxillofacial Trauma \& Reconstruction, 8(1), 1-13. Google Scholar

Guerreschi, Pierre, \& Labbé, Daniel. (2019). Sequelae of facial palsy: A comprehensive treatment. Plastic and Reconstructive Surgery, 144(4), 682e-692e. Google Scholar

Heckmann, Josef Georg, Auff, E., Bischoff, C., Glocker, F. X., Lang, P., Urban, P., \& Weder, B. (2008). Idiopathische Fazialisparese (Bell's palsy). Kommission "'Leitlinien Der Deutschen Gesellschaft Für Neurologie"”'(Ed) Leitlinien Für Diagnostik Und Therapie in Der Neurologie. Stuttgart, New York, 547-553. Google Scholar

Holland, N. Julian, \& Bernstein, Jonathan M. (2014). Bell's palsy. BMJ Clinical Evidence, 2014. Google Scholar

Mistry, Rakesh K., \& Al-Sayed, Ahmed A. (2020). Facial Nerve Trauma. Google Scholar

Murthy, J. M. K., \& Saxena, Amrit B. (2011). Bell's palsy: Treatment guidelines. Annals of Indian Academy of Neurology, 14(Supp11), S70. Google Scholar

Mustafa, Ahmed Hassan Kamil, \& Sulaiman, Ahmed Mohammed. (2018). The epidemiology and management of Bell's palsy in the Sudan. The Open Dentistry Journal, 12, 827. Google Scholar

Newadkar, Ujwala R., Chaudhari, Lalit, \& Khalekar, Yogita K. (2016). Facial palsy, a disorder belonging to influential neurological dynasty: Review of literature. North American Journal of Medical Sciences, 8(7), 263. Google Scholar.

Somasundara, Dhruvashree, \& Sullivan, Frank. (2017). Management of Bell's palsy. Australian Prescriber, 40(3), 94. Google Scholar

Volk, Gerd F., Pantel, Mira, \& Guntinas-Lichius, Orlando. (2010). Modern concepts in facial nerve reconstruction. Head \& Face Medicine, 6(1), 1-11. Google Scholar

Warner, Matthew J., Hutchison, Julia, \& Varacallo, Matthew. (2020). Bell palsy. StatPearls [Internet]. Google Scholar

Walker NR, Mistry RK, Mazzoni T. (2021). Facial Nerve Palsy. In: StatPearls [Internet]. Treasure Island (FL): StatPearls Publishing; 2021 Jan-. Available from: Google Scholar. Google Scholar

Zhang, Wenjuan, Xu, Lei, Luo, Tingting, Wu, Feng, Zhao, Bin, \& Li, Xianqi. (2020). The etiology of Bell's palsy: a review. Journal of Neurology, 267(7), 1896-1905. Google Scholar 
Gunawan, Inas Hanan Farihah, Lisa Raihan Lutfia, Muhamad Mahfuzzahroni, Rizka Febriya Moestafa

Zhao, Yang, Feng, Guodong, \& Gao, Zhiqiang. (2015). Advances in diagnosis and nonsurgical treatment of Bell's palsy. Journal of Otology, 10(1), 7-12. Google Scholar

First publication right:

Jurnal Syntax Fusion: Jurnal Nasional Indonesia

This article is licensed under:

(c) (7) (? 